\title{
Produksi: Telaah Pemikiran Muhammad Abdul Mannan Dalam Ekonomi Islam (Studi Kasus Produksi Garam Rakyat Madura)
}

\author{
Iwan Hidayat \\ Mahasiswa Pascasarjana, Program Studi Ekonomi Syariah, IAIN MADURA \\ Email Korespondensi : iwanhidayat119@gmail.com
}

\begin{abstract}
Production is the provision of goods and services with due regard to the value of justice and benefit to society. Production also has an important role in determining the standard of human life and the prosperity of a nation. In this study, the focus is on salt production in Madura. Salt is a white solid object in the form of crystals which is a collection of compounds with the largest portion of sodium chloride $(\mathrm{NaCl})$ and other compounds such as Magnesium Chloride, Magnesium Sulfate, Calcium Chloride, etc. Broadly speaking, Islamic economics is a science that studies human behavior in an effort to meet needs with limited means of fulfilling needs within the framework of Islamic Sharia. The approach used is a qualitative approach with the type of case study research, namely research on humans (can be a group, and individuals), events, settings in depth. As well as data collection techniques are observation, interviews and documentation. This case study is very relevant and is in line with the use of a modern tool in the use of salt production in Madura, the first to increase production and improve the quality of Madurese and national salt. The emphasis is on quality, quantity, maximization and participation in the production process which provides different functions in the production process.
\end{abstract}

Keywords: Produksi, Garam, Ekonomi Islam

Saran sitasi: Hidayat, I. (2021). Produksi: Telaah Pemikiran Muhammad Abdul Mannan Dalam Ekonomi Islam (Studi Kasus Produksi Garam Rakyat Madura). Jurnal Ilmiah Ekonomi Islam, 7(01), 230-234. doi:http://dx.doi.org/10.29040/jiei.v7i1.1666

\section{DOI: http://dx.doi.org/10.29040/jiei.v7i1.1666}

\section{PENDAHULUAN}

Produksi adalah kegiatan manusia untuk menghasilkan barang dan jasa yang kemudian dimanfaatkan oleh konsumen. Secara teknis produksi adalah proses mentransformasi input menjadi output, tetapi definisi produksi dalam pandangan ilmu ekonomi jauh lebih luas. Produksi juga mempunyai peranan penting dalam menentukan taraf hidup manusia dan kemakmuran suatu bangsa. Kegiatan produksi dalam perspektif ekonomi Islam adalah terkait dengan manusia dan eksistensinya dalam aktivitas ekonomi, produksi merupakan kegiatan menciptakan kekayaan dengan pemanfaatan sumber alam oleh manusia.

Berproduksi lazim diartikan menciptakan nilai barang atau menambah nilai terhadap sesuatu produk, barang dan jasa yang diproduksi itu haruslah hanya yang dibolehkan dan menguntungkan (yakni halal dan baik) menurut Islam. Islam memandang setiap amal perbuatan yang menghasilkan benda atau pelayanan yang bermanfaat bagi manusia atau memperindah kehidupan mereka dan menjadikannya lebih makmur dan sejahtera. Produksi dapat dilakukan dalam bidang apa saja, salah satunya dalam bidang Pertambakan. Pertambakan ada beberapa banyak macamnya salah satunya adalah tambak garam.Garam merupakan benda padatan berwarna putih berbentuk kristal yang merupakan kumpulan senyawa dengan bagian terbesar Natrium Chlorida $(\mathrm{NaCl})$ serta senyawa lainnya seperti Magnesium Chlorida, Magnesium Sulfat, Calsium Chlorida,dll. Adapun dalam kegiatan memproduksi garam, masyarakat masih menggunakan cara konvensional dan produksi menggunakan geomembran,

Dalam hal ini Abdul Manan ketika menjelaskan pengertian ekonomi Islam menyebutkan "Islamic economics is a social science which studies the economics problems of a people imbued with the 
values of islam". Dimana menurut beliau ilmu ekonomi Islam adalah ilmu pengetahuan sosial yang mempelajari masalah-masalah ekonomi masyarakat yang diilhami oleh nilai-nilai Islam. Adapun dalam penjelasan diatas ingin lebih mengetahui bagaimana relevansinya dari kegiatan produksi garam di Madura ditinjau dari pemikiran ekonomi Islam oleh Muhammad Abdul Mannan.

\section{METODE PENELITIAN}

Dalam sebuah penelitian diperlukan sebuah metode sebagai cara untuk mencapai tujuan, adapaun pendekatan yang digunakan dalam penelitian ini adalah pendekatan kualitatif, yaitu suatu pendekatan penelitian yang digunakan untuk mengumpulkan informasi mengenai subjek penelitian pada suatu periode tertentu dengan mendeskripsikan segala atau keadaan yang ada. Adapun jenis penelitian ini termasuk pada jenis penelitian studi kasus, merupakan penelitian dimana peneliti menggali suatu fenomena tertentu (kasus) dalam waktu dan kegiatan (program, even, proses, institusi atau kelompok sosial) serta mengumpulkaninformasi secara terperinci dan mendalam dengan menggunakan berbagai prosedur pengumpulan data selama periode tertentu.

\section{HASIL DAN PEMBAHASAN}

\subsection{Hasil penelitian}

Proses produksi garam yang sederhana adalah menguapkam alir laut sehingga mineral-mineral yang ada di dalamnya mengendap. Hanya saja mineralmineral yang kurang diinginkan sedapat mungkin hanya sedikit yang dikandung oleh garam yang diproduksi. Lahan pembuatan garam dibuat berpetakpetak secara bertingkat, sehingga dengan adanya gaya gravitasi air dapat mengalir ke hilir kapan saja dikendekaki oleh petani garam tersebut.

Adapun tahapan proses pembuatan garam sebagai berikut:

a. Pengeringan lahan

b. Pengolahan air peminian/waduk

c. Pengolahan air dan tanah

d. Proses kristalisasi

e. Proses pungutan

f. Proses Pencucian

Dari tahapan proses produksi garam ada juga faktor-faktor yang mempengaruhi produksi garam, yaitu:
a. Air laut
b. Keadaan Cuaca

c. Tanah

d. Pengaruh air

Sebagaimana garam yang dihasilkan dengan menggunakan alat geomembran memiliki warna yang lebih putih bening dan termasuk dalam garam kualitas 1. Garam yang dihasilkan lebih baik (warna dan ukuran) dibandingkan dengan garam yang dihasilkan dengan cara konvensional. Hal ini disebabkan karena dengan menggunakan geomembran akan mencegah air kontak langsung dengan tanah serta mencegah terikutnya kotoran tanah pada permukaan meja kristalisasi pada saat pemungutan garam.

Pada hal ini jelas dengan adanya teknologi yang baru bisa menambah pendapatan produksi garam nasional tentunya dengan kualitas yang bagus. Sehingga tidak harus menginpor garam dari luar negeri terus-menerus.

Adapun dalam hal ini peneliti merangkum bagaimana perbedaan dari bagaimana proses prosuksi garam rakyat di pulau Madura , diambil dari beberapa referensi.

\begin{tabular}{|c|c|c|c|}
\hline & Perbedaan & Konvensional & Geomembran \\
\hline 1 & $\begin{array}{l}\text { Proses } \\
\text { pembuat } \\
\text { an garam }\end{array}$ & $\begin{array}{l}\text { 1. Pengeringan } \\
\text { lahan } \\
\text { 2. Selinder lahan } \\
\text { meja garam } \\
\text { menggunakan } \\
\text { guluk } \\
\text { 3. Pengelolaan air } \\
\text { peminian/ } \\
\text { waduk } \\
\text { 4. Pengelolaan air } \\
\text { tua } \\
\text { 5. Masukkan air } \\
\text { tua ketempat } \\
\text { meja garam } \\
\text { yang sudah } \\
\text { kering } \\
\text { 6. Proses } \\
\text { kristalisasi } \\
\text { 7. Proses } \\
\text { pengutan } \\
\text { panen garam } \\
\text { 8. Kembali ke } \\
\text { proses awal } \\
\text { yaitu a } \\
\text { pengeringan } \\
\text { lahan garam } \\
\text { seperti semula }\end{array}$ & $\begin{array}{l}\text { 1. Pengeringan } \\
\text { lahan } \\
\text { 2. Selinder lahan } \\
\text { meja garam } \\
\text { menggunakan } \\
\text { guluk } \\
\text { 3. Pengelolaan } \\
\text { air } \\
\text { peminian/wad } \\
\text { uk } \\
\text { 4. Pengelolaan } \\
\text { air tua } \\
\text { 5. Pemasangan } \\
\text { alat } \\
\text { geomembran } \\
\text { ketempat meja } \\
\text { garam yang } \\
\text { sudah kering } \\
\text { dan rata } \\
\text { 6. Masukkan air } \\
\text { tua ketempat } \\
\text { meja garam } \\
\text { yang sudah } \\
\text { terpasang alat } \\
\text { geomembran } \\
\text { 7. Proses } \\
\text { kristalisasi }\end{array}$ \\
\hline
\end{tabular}




\begin{tabular}{|c|c|c|c|}
\hline \multicolumn{4}{|c|}{ Jurnal Ilmiah Ekonom } \\
\hline \multicolumn{2}{|c|}{ NoPerbedaan } & Konvensional & Geomembran \\
\hline & & & $\begin{array}{l}\text { 8. } \text { Proses } \\
\text { pungutan } \\
\text { panen garam } \\
\text { 9. } \text { Kuras air sisa } \\
\text { pungutan } \\
\text { garam, } \\
\text { kemudian } \\
\text { tinggal } \\
\text { masukkan } \\
\text { kembali air tua } \\
\text { yang } \\
\text { disediakan. }\end{array}$ \\
\hline 2 & Hasil & $\begin{array}{l}\text { 1. Garam agak } \\
\text { kekuningan } \\
\text { 2. Masih } \\
\text { bercampur } \\
\text { dengan polutan } \\
\text { tanah } \\
\text { 3. Kristal garam } \\
\text { agak halus. }\end{array}$ & 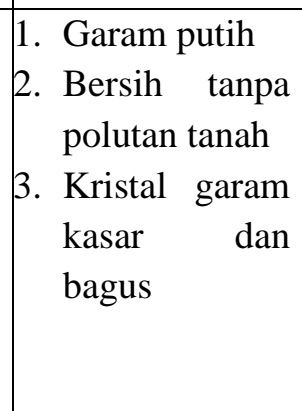 \\
\hline 3 & $\begin{array}{l}\text { Waktu } \\
\text { untuk } \\
\text { panen } \\
\text { garam }\end{array}$ & $\begin{array}{l}\text { 1. Dari proses } \\
\text { memasukkan } \\
\text { air tua ke meja } \\
\text { garam, harus } \\
\text { menunggu 22- } \\
25 \text { hari baru } \\
\text { bisa panen. }\end{array}$ & $\begin{array}{l}\text { 1. Dari proses } \\
\text { memasukkan } \\
\text { air tua ke } \\
\text { tempat meja } \\
\text { garam yang } \\
\text { sudah } \\
\text { terpasang alat } \\
\text { geomembrann } \\
\text { membutuhkan } \\
\text { waktu } 15-17 \\
\text { untuk bisa } \\
\text { panen. }\end{array}$ \\
\hline 4 & $\begin{array}{l}\text { Kualitas } \\
\text { Garam }\end{array}$ & $\begin{array}{l}\text { 1. Garam K3 } \\
\text { 2. Garam K2 }\end{array}$ & $\begin{array}{ll}\text { 1. } & \text { Garam } \\
& \text { Premium } \\
\text { 2. } & \text { Garam K1 } \\
\text { 3. } & \text { Garam K2 }\end{array}$ \\
\hline
\end{tabular}

Sebagaimana menurut Muhammad Abdul Mannan:

"Produksi berarti diciptakannya manfaat, seperti juga konsumsi adalah pemusnahan produksi itu sendiri. Produksi tidak berarti menciptakan secara fisik sesuatu yang tidak ada, karena tidak seorang pun dapat menciptakan benda. Dalam pengertian ahli ekonomi, yang dapat dikerjakan manusia hanyalah membuat barang-barang menjadi berguna, disebut dihasilkan".

Sebagaimana sangat relevansinya dari pendapat seorang tokoh ekonomi kontemporer, dari bagaimana penggunaan alat geomembran sebagai penambah pendapatan produksi garam rakyat di Madura yang sangat efesien,dan bagaimana kegunaan dari alat geomembran tersebut menjadi barang guna yang dihasilkan dari kegiatan produksi.

\subsection{Pembahasan}

\section{a. Biografi Muhammad Abdul Mannan}

Muhammad Abdul Mannan dilahirkan di Bangladesh pada 1938. Sesudah menerima gelar Master di bidang Ekonomi dari Universitas Rasjshahi pada 1960, ia bekerja di berbagai kantor ekonomi pemerintah di Pakistan. Pada 1970, ia pindah ke Amerika Serikar dan di sana ia mendaftarkan diri di Michigan State University untuk program MA (Economics). Pada 1973 ia lulus program doktor dari universitas yang sama, dalam bidang minat beberapa bidang ekonomi seperti Ekonomi Pendidikan, Ekonomi Pembangunan, Hubungan Industri dan Pembangunan. Pengungkapannya atas ekonomi Barat, terutama ekonomi mainstream, adalah bukti bahwa ia memakai pendekatan mainstream di dalam pemahamannya terdapat ekonomi Islam.

\section{b. Produksi}

Kata "produksi" telah menjadi kata Indonesia, setelah diserap di dalam pemikiran ekonomi bersamaan dengan kata "distribusi". Dalam kamus InggrisIndonesia kata "production" secara liguistik mengandung arti penghasilan. Dalam sistem ekonomi islam, kata "produksi" merupakan salah satu kata kunci terpenting. Dari konsep gagasan produksi ditekankan bahwa tujuan utama yang ingin dicapai kegiatan ekonomi yang diteorisasikan sistem ekonomi islam adalah untuk kemaslahatan, individu (self interest) dan kemaslahatan (social interest) secara berimbang.

Faktor-faktor produksi dapat dibedakan menjadi empat golongan, yaitu; tenaga kerja, tanah, modal dan organisasi. Di dalam teori ekonomi analisa produksi dimisalkan bahwa tiga faktor produksi yang belakang (tanah, modal dan organisasi) adalah tetap jumlahnya. Hanya tenaga kerja yang dipandang sebagai faktor produksi yang berubah-ubah jumlahnya. 
Menurut Adiwarman A. Karim Produksi adalah proses yang telah terlahir dimuka bumi ini semenjak manusia menghuni planet ini. Produksi sangat prinsip bagi kelangsungan hidup dan juga peradaban manusia dan bumi. Sesungguhnya produksi lahir dan tumbuh dari menyatunya manusia dan alam. Maka untuk menyatukan antara manusia dan alam ini allah telah menetapkan bahwa manusia berperan sebagai khalifah. Sedangkan secara umum Produksi adalah hasil, penghasilan, barang yang dibuat atau dihasilkan atau suatu kegiatan untuk meenimbulkan dan menaikan faedah atau nilai suatu barang atau jasa.

\section{Prinsip-Prinsip Produksi Dalam Ekonomi Islam}

Dalam definisi tentang produksi, yaitu aktivitas menciptakan manfaat di masa kinidan mendatang. Dalam Al-Qur'an dan Hadis Rasulullah SAW memberikan arahan mengenai prinsip-prinsip produksi sebagai berikut:

1) Tugas manusia dimuka bumi sebagai khalifah Allah adalah memakmurkan bumi dengan ilmu dan amalnya. Karena sifat tersebut juga harus melandasi aktivitas manusia dalam pemanfaatan bumi dan segala isinya.

2) Islam selalu mendorong kemajuan di bidang produksi. Menurut Yusuf Qardhawi, Islam membuka lebar penggunaan metode ilmiah yang didasarkan pada penelitian, eksperimen dan sebagainnya. Akan teteapi Islam tifak membenarkan penuhanan terhadap hasil karya ilmiah.

3) Teknik produksi diserahkan kepada keinginan dan kemapuan manusia. Nabi pernah bersabda: "Kaliah lebih mengetahui urusan dunia kalian ".

4) Dalam berinovasi dan bereksperimen, pada prinsipnya agama Islam menukai kemudahan, menghindari mudarat dan memaksimalkan manfaat. Dalam Islam tidak terdapat ajaran yang memerintahkan membiarkan segala urusan berjalan dalam kesulitan, dan sebagainya

\section{c. Garam}

Garam merupakan salah satu nahan kimiawi untuk stabilisasi tanah lempung, struktur garam $(\mathrm{NaCl})$ meliputi alion ditengah dan kaiton menempati pada rongga otcahedral. Larutan garam juga merupakan suatu elektrolit yang mempunyai gerakan brown dipermukaan yang lebih besardari gerakan brown pada air murni sehingga bisa menurunkan air dan larutan, ini merambah gaya kohesi antar partikel lebih rapat.

Garam merupakan salah satu bahan kimia yang sering dimanfaaatkan oleh manusia khususnya dalam bisang komsumsi. Garam diperoleh dari tiga cara, yaitu penguapan air laut dengan sinar matahari, penambangan batuan garam (rock salt) dan air sumur garam (brine). Garam hasil tambang berbeda-beda dalam komposisinya, tergantung pada lokasi, namun biasanya mengandung lebh dari $95 \% \mathrm{NaCl}$. Garam sebagai salah satu kebutuhan terpenting dalam kehidupan sehari-hari. Garam termasuk komuditas yang penting sebagai bahan pangan dan bahan baku industri. Garam juga berperan sebagai sumber elektrolit bagi tubuh manusia, sehingga kegiatan produksi, penyediaan, pengadaan dan distribusi garam menjadi sangat penting.

\section{d. Ekonomi Islam}

Ekonomi Islam dalam bahasa Arab diistilahkan dengan al-iqtishad al-islami. Aliqtishad secara bahasa berarti al-qashdu yaitu pertengahan dan berkeadilan. Iqtishad (ekonomi) didefinisikan dengan pengetahuan tentang aturan yang berkaitan dengan produksi kekayaan, mendistribusikan, dan mengomsumsinya. Ekonomi pada umumnya didefinisikan sebagai kajian tentang perilaku manusia dalam hubungannya dengan pemanfaatan sumbersumber produksi yang langka untuk diproduksi dan dikomsumsi.

Mohammad Abdul Mannan mendefinisikan ekonomi islam sebagai sebuah ilmu sosial yang mempelajari masalah-masalah ekonomi bagi suatu masyarakat yang diilhami oleh nilai - nilai islam. Ekonomi islam itu berhubungan dengan produksi, distribusi dan konsumsi barang serta jasa didalam kerangka masyarakat islam yang didalamnya jalan hidup islami ditegakkan sepenuhnya.

\section{KESIMPULAN}

Dalam kajian ekonomi khususnya tentang Produksi Muhammad Abdul Mannan dalam sistem produksi lebih menekankan pada konsep kesejahteraan ekonomi yang terdiri dari peningkatan pendapatan yang diakibatkan oleh meningkatnya 
produksi dari barang yang bermanfaat melalui pemanfaatan sumber-sumber daya secara maksimum (baik manusia maupun benda) serta melalui partisipasi dari jumlah maksimum orang dalam proses produksi. Pada studi kasus tersebut sangat relevan dan seaarah dengan adanya penggunaan sebuah alat modern dalam penggunaan produksi garam di Madura, yang pertama untuk mnambah produksi dan meningkatkan kualitas garam madura dan nasional. Penekanannya pada kualitas, kuantitas, pemaksimalan dan partisipasi dalam proses produksi yang memberikan fungsi yang berbeda dalam proses produksi. Jadi tidak ada lagi perusahaan yang hanya sebagai pemasok komoditas, tetapi juga sebagai wali-bersama dengan Negara, untuk meningkatkan kesejahteraan ekonomi.

\section{UCAPAN TERIMAKASIH}

Penulis menyampaikan terima kasih kepada seluruh pihak yang sudah memberikan dukungan dan doa sehingga penulis dapat menyelesaikan penelitian ini. Terutama kepada Orang Tua penulis , yaitu Bapak Absari dan Ibu Subaidah. Tanpa danya doa dari semua yang sudah berkontribusi maupun tidak sampai saat ni penelitian ini tidak akan pernah terealisasi.

\section{REFERENSI}

Abdul Mannan, Teori dan Praktek Ekonomi Islam, (Yogyakarta: Dana Bakti Prima Yasa, 1997), h. 19

Adiwarman Karim, Ekonomi Mikro Islami, (Jakarta : PT. RajaGrafindo Persada, 2007), Cet. Ke-1, h.

Emzi, MetodologiPenelitian Kualitatif: Analisis Data, (Jakarta: PT. Rajagrafindo Persada,2012), hlm.20

Heri Sudarsono, Konsep Ekonomi Islam, (Yogyakarta: CV Adipura, 2004), Cet. Ke-3, h.

Imron, Kamus Bahasa Indonesia, (Surabaya: Karya Ilmu, 1992), Cet. Ke-3, h. 158

Lukman Hakim,Prinsip-Prinsip Ekonomi Islam (Surakarta:PT Gelora Aksara Pratama,2012), hlm.64

Mahfud Effendy, dkk. “ Intensifikasi Lahan Garam rakyat Di kabupaten Sumenep, hlm. 30-31.

Mawardi, Ekonomi Islam, (Pekanbaru : UNRI Press, 2007), Cet-1, h. 64
Muhammad Abdul Mannan, Teori dan Praktek Ekonomi Islam, (Yogyakarta: PT. Dana Bhakti Prima Yasa, 1997), Cet. Ke-1, h. 54

Muhammed Aslam Haneef, .Pemikiran Ekonomi Islam Kontemporer. (Jakarta: Rajawali pers.2010)

Mukhtar, Metode Praktis Penelitian Deskriptif Kualitatif, (Jakarta: Referensi,2013), hlm.11

Rozalinda ," Ekonomi Islam: Teori dan Aplikasinya pada Aktivitas Ekonomi", (Jakarta , PT. Rajagrafindo Persada,2014

Dini Purbani. Proses Pembentukan Kristalisasi Garam, Pusat Riset Wilayah Laut dan Sumberdaya Nonhayati Badan Riset Kelautan dan Perikanan, departemen Kelautan dan Perikanan.

http://www.oocities.org/tisaktigeologi84/garam. pdf., hlm3-9.

Herman dan Willy Joetr. Pengaruh Garam Dapur (NaCi) Terhada Kembang Susut Tanah Lempung Vol 17, No.1.(Jurnal: Jurnal Momentum. 2015)https://docplayer.infpo/storage/54/352402 58/1553707935/MsgvvbPsS\&AbomBonTc4nw/ 35240258.pdf, hlm.13.

Khoironni Devi Maulana, Muhammad Mu'min, Priyus Eka Manunggal, Baiti Rohmawati dan Rahmawati. Peningkatan Kualitas Garam Bledug Kuwu Melalui Proses Rekristalisasi dengan Pengikat Pengotor $\mathrm{CaO}, \mathrm{Ba}(\mathrm{OH}) 2$, dan (NH4)2CO3 Journal of Creativity student 2. 2017.

https:/journal.unnes.ac.id/nju/index.php/jcs/aricl e/download/13237/7359, hlm. 43

Misbahul Ali. Prinsip Dasar Produksi Dalam Ekonomi Islam. Vol. 5 No.1. (Jurnal: Lisan AlHal.

2013),.https://adoc.tips/download/prinsip.dasar. produksi.dala,.ekonomi.islam.oleh.misbahul.ali. html,hlm.34

Muhammad Turmudi. Produksi Dalam Perspektif Ekonomi Islam. Vol. XVIII, No. 1 Jurnal: Jurnal Pemikiran Islam, Islamadina. 2017, htpps://media.neliti.com/media.publications/705 13.Id-produksi-dalam-perspektid-ekonomiislam.pdf, hlm 43. 